\title{
CONFORMITY IN CHRIST
}

\author{
K. Waaijman ${ }^{1}$
}

\begin{abstract}
This essay investigates the notion of conformity in Christ as it is part of a comprehensive, multilayered process of transformation. In the first part it focuses on the process of transformation in creation, re-creation, conformity, love and glory. In the second part it discusses transformation in Christ by looking at conformation and unformation. From the viewpoint of spirituality, conformity in Christ is part of a comprehensive, multilayered process of transformation. After a short overview of this process, conformity in Christ will be discussed.
\end{abstract}

\section{THE TRANSFORMATION PROCESS}

The word "transformation" is part of a richly varied semantic field: to form, deform, reform, be conformed and transformed. Throughout the centuries spiritual authors have used this semantic field to bring out the inner logic of the spiritual way. ${ }^{2}$ For them this semantic field — and within it especially the term "transformation" - refers to the most significant transitions in the divine-human relational process. In John of the Cross, for example, the spiritual way which passes between "the substantial union by which God keeps man in being," and "the union-by-likeness" by which humans lose themselves in God, ${ }^{3}$ is conceived in terms of form, deformation, reformation, conformity and transformation, ${ }^{4}$ with the last term, in keeping with the tradition, in-

1 K. Waaijman, Research Fellow, Department of New Testament, Faculty of Theology, University of the Free State, Bloemfontein; and Director of the Titus Brandsma Institute in Nijmegen.

2 For an initial presentation of this semantic field, see Sandaeus (1963:150-152, 177-178, 354-356).

3 John of the Cross, The ascent of Mount Carmel II, 5, 3; Spiritual Canticle B 11, 4. The translation used is that of Kavanaugh \& Rodriguez (1979).

4 In John of the Cross the semantic field conformar, conforme, conformidad, deiforme, deiformidad, forma, formal, formalment, formar, reformación, reformar, transformación, transformar occurs 524 times. 
dicating the intentionality of the spiritual way. ${ }^{5}$ Also contemporary authors frequently use the word "transformation" precisely in the places where they seek to conceptualise spirituality in terms of its essence. ${ }^{6}$ Thus Schneiders writes that "spirituality as an academic discipline studies the transformative Christian experience as such."7

In the transformation process we distinguish five layers: (1) the transformation from non-being into being - the creation by God; (2) transformation from being deformed to being re-formed in God's re-creation of man; (3) someone's becoming conformed to a divine-human transformation model which introduces a person into divine reality; (4) transformation in love in which the soul is led into God, while God takes up his abode in the soul; (5) the transformation in glory which awaits us after this life but of which the transformation in love already contains a sketch.

\subsection{Transformation in creation}

In a very ancient song fragment (Ps. 139:13-16), ${ }^{8}$ the transition from non-being into being is verbalised as follows:

Yes, You acquired my kidneys, wove me together in my mother's belly.

I want to thank you, because I am awesomely exceptional

- peculiar are your makings

and my soul feels it extremely!

My strength was not hidden from you, when I was made in secret, embroidered in the depths of the earth. Your eyes saw me - still a ball of yarn;

5 In the concordance on the works of John of the Cross, there are more than 40 references to "transformation in God," to "transform in God," and to the idea that God "transforms the soul in himself."

6 By way of example, a few titles: Fox (1982:74-80); Agnew (1974); Sustar (1992); Turner (1964); Vaughan-Lee (1995); Vale (1990); Frohlich (1990); Wiethaus (1996); Moseley (1991).

7 Schneiders (1998); also cf. Coleman (1997) who regards spirituality "as the key to transformation."

8 We still find interplay here between becoming out of mother earth and birth from the physical mother. Cf. Westermann (1984:26, 36, 125, 204). 
in your story were written

all the days, formed before

even one of them was there (Ps. 139:13-16).

The fact that God forms our being, can penetrate and permeate the human consciousness. Therefore, in the midst of the story of his marvellous formation by God the Psalmist cries out: "My soul feels it extremely!" (Ps. 139:14). The soul feels like clay on a potter's wheel (2 Sam. 17:28; Isa. 18:23-6; 29:16; 30:14; 41:25; 45:9; Jer. 18:2-6; 19:111). This imagery for the Creator-creature relation ${ }^{9}$ is particularly useful for making the soul conscious of its transformation from non-being into being. This is the reason why God sent Jeremiah to the potter's house. The potter was just making a vessel on his wheel (Jer. 18:1-3).

Whenever the vessel he was making came out wrong, as happens with clay in the hand of a potter, he would start over and make of it another pot, as it seemed good to the potter (Jer. 18:4).

The transformation from non-form to form is in the hands of the One who forms. Eckhart says,

I have within my soul a strength that is totally receptive to God. I am as certain as I am that I am alive that nothing is so near to me as God. God is nearer to me than myself. My being depends on the fact that God is near to me and present for me. He is also near and present for a stone or piece of wood, but they know nothing about this fact. If a piece of wood knew about God and perceived how near he is to it, as the highest angel perceives this fact, then the piece of wood would be just as happy as the highest angel. ${ }^{10}$

\subsection{Transformation in re-creation}

Humans make the transition from non-being into being every moment of their life. This transition substantially unites them with their Creator. Once our form exists, however, it can open itself up to its Creator or shut itself up in itself (Gen. 6:5; 8:21; 1 Chron. 28:9; cf. Deut. 31:21). From within the depths of their heart people can go in two directions: there is in them an orientation toward the good (1 Chron. 29:18; cf. Isa. 26:3) and an orientation toward the evil (Gen. 6:5; 8:21). In rabbinic literature these two orientations (yetser) jointly point (as a merism)

9 God is the subject 42 times of the 63 times the verb yatsar occurs.

10 Meister Eckhart, Scitote, quia prope est regnum Dei, in Quint (1976:141-142). 
to the dramatic pre-given reality in people that at any moment they can let themselves be pulled in two directions (Strack \& Billerbeck 1924:466-483).

Those who let themselves be defined by finite forms finitise themselves (John of the Cross, The ascent of Mount Carmel I, 4, 3-4). Included among these finite forms are "the jewels of images and supernatural forms" (ibid. II, 16, 4). All these "forms are represented in some limited mode or manner" (ibid. II, 16, 7). When people let themselves be defined by finite creatures they get detached from God.

Paul says: "Do not follow the pattern of this world but be re-formed by the renewal of your mind" (Rom. 12:2). The "divine passive" indicates that the reformation proceeds from God. Humans cooperate with this reformation: a continual renewal of the mindset whose purpose is to "recognise what is the will of God - what is good and acceptable and perfect" (Rom. 12:2). The real reformation (metamorphosis) proceeds from God: the pattern (schèma) of the world must be abandoned, the form of God must again gain its grip on us. The spiritual writers continually thematise the field of tension: formation-reformationtransformation:

People must turn away from that deformation in which, by worldly desires, they were conformed to this world, and be re-formed by him (Augustine, De Trinitate lib. 14 cap. 16, 22; PL 42, 1053).

The tradition illuminates several aspects of this re-formation.

\subsection{Transformation in conformity}

Reformation is aimed at the recovery of the original form of man, the image of God. To that end it orients itself to a form which makes present the original figure. The reformation of the original image of God in man and conformation to the divine-human figure are extensions of each other.

We are formed after God's image, deformed by sin, reformed by grace by becoming conformed to Christ, and finally transformed in glory (Casey 1999:86).

By the interiorisation of Christ's life the original image rises to the surface and a person achieves union with God who is above all crea- 
tures and surpasses all knowledge. ${ }^{11}$ The spiritual form has a mediating effect which is grounded in its divine-human structure. We clearly observe this in the Letter to the Philippians. The Messiah is pictured here in "the form of a slave" and in "the form of God" (Phil. 2:7). The notion of "form" refers to a specific mode of being: the "form of a slave" refers to the status of a slave; the "form of God" refers to the sphere of the divine. The Messiah participates in both modes of being (Pöhlmann 1981:1089-1091). To bring Christians to the perfect knowledge of God,

He who is equal to the Father in divine majesty became like us in the existence of a slave and shapes us into likeness with God. Thus the only Son of God, having become son of man, made many children of human parents into children of God (Augustine, Sermo 194, ch. 3 and 4 [PL 38 1016-1017]; cf. further below).

\subsection{Transformation in love}

Transformation into conformity sees to it "that the sensory and lower part is reformed, purified, and brought into conformity with the spiritual part" (John of the Cross, Spiritual Canticle B, 40, 1). Now the soul is capable of going out to God to be transformed by him. God, conversely, assumes the form of the soul "by totally and completely transforming it in love and glory" (ibid. B, 9, 2). To John of the Cross love and glory describe two phases in the process of glorification. Transformation in love is "the highest state attainable in this life" (ibid. B 12, 8). Transformation in glory "will be effected perfectly in heaven, in life with God, in all those who merit seeing themselves in God" (ibid. B, $12,8)$. The peculiar nature of transformation in love is that love prompts God and man to rest completely in each other:

Love produces such likeness in this transformation of lovers that one can say each is the other and both are one (ibid. B, 12, 7).

The lovers, in being with the other, completely give themselves up to the other:

In the transformation of love each gives possession of self to the other, and each leaves and exchanges self for the other. Thus each one lives in the other and is the other, and both are one in the transformation of love (ibid. B, 12, 7).

11 Bonaventure, Itinerarium. De weg die de geest naar God voert, in: Van Winden (1996: 159). 
In the transformation in love three distinct perspectives stand out: the soul's outgoing movement toward God who draws it into himself; the movement of God toward the soul to take up residence in it; the intimacy of the Spirit who holds sway between the two, a reality which is called "spiritual marriage" (ibid. B, 22, 2-5).

\subsection{Transformation in glory}

Transformation in love occurs in this life; transformation in glory belongs to the life after this life. About that we as yet know nothing. We only catch a glimpse of it to the degree that our transformation in love contains a sketch of the transformation in glory. John of the Cross says:

Transformed in God, these blessed souls will live the life of God and not their own life - although, indeed, it will be their own life, because God's life will be theirs. Then they will truly proclaim: We live, now not we, but God lives in us. Although transformation in this life can be what it was in St. Paul, it still cannot be perfect and complete, even though the soul reaches such transformation of love as is found in the spiritual marriage, the highest state attainable in this life. Everything can be called a sketch of love in comparison with that perfect image, the transformation in glory (ibid. B, 12, 8).

Transformation in love is a sketch of something else: transformation in glory. However deep and thorough the transformation in love may be, it cannot in this life become complete transformation in glory. That is possible only when this life is relinquished in death.

Since the soul sees that through her transformation in God in this life she cannot, even though her love is immense, equal the perfection of God's love for her, she desires the clear transformation of glory in which she will reach this equality (ibid. $\mathrm{B}, 38,3$ ).

Transformation in glory consists in that the soul then "passes into God (transire in Deum)" (Bernard of Clairvaux, De diligendo Deo 11, 30).

\section{TRANSFORMATION IN CHRIST}

More attention is needed now for the transformation in Christ. Two aspects in this process are important: (1) A process of conformation; (2) A process of unformation. 


\subsection{Conformation}

"Conformation" refers to a process in which a person appropriates for himself (herself) a selected model of transformation in behaviour, thinking and willing, remembering, feeling and focus. In Christian spirituality the central model of transformation is Christ, expressed with Paul's words: "that Christ is formed in you" (Gal. 4:19). Paul is speaking here in the language of pregnancy and birth. Christ must assume form in the church just as a child is formed in the womb. Paul is experiencing birth pangs over this process. Christ is the spiritual form of the Christian life. The spiritual way of Christians is that they are "transformed into a new creation through the Spirit's work of conforming them to the mystery of Christ's death and resurrection" (McGonigle 1993:965). Christian spirituality attempts in all things to conform itself to Christ: "For this did he come, to hand down to us a form and to point out a way," 12 a "form of holiness," (Bernard of Clairvaux, Sermones de psalmo 'Qui habitat' in Quadragesima 14, 5), a "form of perfection" (Bernard of Clairvaux, Vita Sancti Malachiae Episcopi 43).

Crucial for spiritual transformation is the "discernment" between form-adaptation and form-interiorisation. Adaptation is conformity on the external level of behaviour. Interiorisation touches the heart and brings into contact with the inner strengths of the form. In that sense Paul says that there will be people in the last days who, though they possess the formation of piety, deny its power (1 Tim. 3:15). Paul here "discerns" between the "formation" and the "power" of piety. By "formation" Paul means the process of form-adaptation. This process can be accomplished without getting into touch with the core of that piety: the "power" of God. Transformation through conformity presupposes that people will not only appropriate the external form for themselves but through it achieve contact with the divine form which animates it. Seuse (Hofmann 1966:174) writes, "A resigned person must be stripped of his creaturely form, formed in Christ, and transformed by the Deity." Ruusbroec says the same: By conformity to the divine-human form the souls are

12 Bernard of Clairvaux, Sermo in Natali S. Benedicti 8. Cf. the text edition by Leclercq, Talbot \& Rochais (1957-1977). 
both with images and without. They have the images of the life of our Lord, his suffering and his death and all virtue. And in their spirit they are free and idle and empty of all things. And for this reason they are without images and transformed in divine clarity. (...) They go out with the image of the humanity of our Lord (...). They go in without images with the Spirit of our Lord where they find and possess eternal clarity, unfathomable wealth, taste and comfort more than they can grasp or comprehend. ${ }^{13}$

\subsection{Unformation}

The moment when the divine-human form performs its mediating function, the spiritual form and God are one. For that reason Rumi can say that the prophets, God's deputies, do not represent two forms:

To the form-worshiper they are two; when you have escaped from consciousness of form, they are One. Whilst you regard the form, you are seeing double: look not at the eyes, but at the light which flows from them. ${ }^{14}$

You cannot distinguish the light of ten lamps if you look at the lamps: "The lamps are different, but the light is the same: it comes from Beyond. If you keep looking at the lamp, you are lost" (cf. in Nicholson 1995:166). While you look at the form (the lamp) you have to let go of it to receive the divine unity which flows through it (the light). The spiritual form deprives me of every form and all that has been formed, and precisely thus, "naked and unencumbered by images," the soul is "drawn into transformation in God's unity." 15 Transformation brings me "into the form of God" (William of St. Thierry, Meditativae Orationes, 12, 18). All spiritual forms want to take people into God without form. For that reason these forms have to be relinquished so that the soul can fall past them into God's unfathomableness. This unformation in God occurs at all levels but the spiritual authors focus especially on the three faculties: the intellect, the will, and the memory.

The unformation of the intellect. If our intellect is determined by finite forms - and that is inescapable, since the intellect knows by way of finite forms which reach us through the senses (John of the Cross, The

13 John Ruusbroec, Letters I, 98-117. Cf. the text edition of De Baere (1991:528).

14 Rumi, Unity of Spirit, in Nicholson (1995:134).

15 John Ruusbroec, Sparkling Stone, 95-11, in: Opera Omnia 10 (1991:529). 
ascent of Mount Carmel II, 3, 2) - then it will have to be unformed if it is to know the Unformed (ibid. II, 12-16). This unformation concerns both the natural and the supernatural forms. As it concerns the natural objects,

[t]he particular knowledge, forms of things, imaginative acts, and any other apprehensions involving forms and figures are all lost. (...) Transformation in God makes her so consonant with the simplicity and purity of God in which there is no form or imaginative figure, that it leaves her clean, pure, and empty of all forms and figures.

Also the supernatural forms will have to be removed: the soul must "also darken and blind itself in the part of its nature that bears relation to God and spiritual things" (The ascent of Mount Carmel II, 4, 2). Especially the mental representations which occur during meditation (Jesus against the scourging column, God seated on his throne, and so forth) must be relinquished (ibid. II, 12-16). These considerations, forms, and manners are necessary for beginners to ignite their soul in love via the sensory level. One must go through them, not remain stuck in them, just as one must not remain half-way up a stairway on the assumption that one now has the hoped-for perspective. For the rest, one needs to note carefully at what moment one relinquishes the forms. One must not cut short the process of conformation too early. Nor must one do it too late, or one gets entangled in the form (ibid. II, 13,1).

The unformation of the will. The typical problem of the will is that it wills the other but at the same time realises that that the other has his or her own inner story. It cannot "invent" the other. To the extent that the will seeks the other it is dependent on the other. The will can only "be formed in all patience" by submitting "to the will of its Shaper" (William of St. Thierry, Epistola 68). The will must be denuded of everything that is not the will of God. Positively this means that the soul must conform itself completely to the will of God:

The person of whom we speak prays to God as God. (...). He does not conform God to himself but himself to God. Those who conform themselves to God do not ask of God anything for themselves and ask nothing but God himself as God is for himself (William of St. Thierry, Super Cantica 23).

The will only wants what God's will is. God's will gently and tenderly makes itself felt in the will of man, drives out all hardness and 
self-orientation, and transforms the will in himself (John of the Cross, Living flame of love I, 23). Through this transformation of the will

the soul performs in this measure in God and through God what he through himself does in it. For the will of the two is one will (ibid. III, 78).

God and the will breathe into each other, move on all levels from the same base to the same goals (John of the Cross, The ascent of Mount Carmel II, 5, 4). At that moment the will, divested of itself, is solely open to being influenced by God without form:

You have formed the will without form because You are neither form nor something formed. Your love cannot consist in any single form. Hence it can also not be formed into something that has been formed in some fashion (William of St. Thierry, Meditativae Orationes 12, 17).

The unformation of the memory. Everything that has passed through the soul leaves a track behind in the memory (John of the Cross, The ascent of Mount Carmel III, 7, 1). That is also true for spiritual forms - whatever the spiritual man has experienced (ibid. III, 8,1), supernatural images (ibid. III, 12, 1) or spiritual communications (ibid. III, 14, 1). God, however, cannot be grasped in any single form or perceptible communication, nor in any image of the memory:

God has no form or image comprehensible to the memory. Therefore the memory is without form, figure, or fantasy when united to God (ibid. III, 2, 4).

If the memory is to be united with God, the memory needs to be unformed:

The annihilation of the memory in regard to all forms is an absolute requirement for union with God: the memory must empty and divest itself of all communications and forms. (...) Union with God cannot be wrought without a complete separation of the memory from all forms that are not God (idem).

Initially this emptying will elicit fear and disorientation but gradually to the degree that God becomes the form of the memory, a person will feel secure:

Neither should there be any fear because the memory is void of forms and figures. Since God is formless and figureless, the memory walks safely when empty of form and figure, and it draws closer to God (Living flame of love III, 52). 


\section{CONCLUSION}

Conformity in Christ cannot be isolated from the multilayered process of transformation, encompassing, on the one hand, processes of creation and recreation, leading to the ability to grow in conformity with Christ, on the other hand, initiating into processes of transformation in love and glory, as the completion of the conformity in Christ.

The process of conformity in Christ itself is a double-sided process. It is a continuous process of conformation, but at the same time a process of unformation, caused by the unformed infinity of God.

\section{BIBLIOGRAPHY}

\section{AGNEW M}

1974. Transformed Christians. New Testament messages on holy living. Kansas City.

BONAVENTURE

1996. Itinerarium. De weg die de geest naar God voert (transl. \& comm. J van Winden). Assen.

\section{CASEy M}

1999. Suspensa expectatio. Guerric of Igny on Waiting for God. Studies in Spirituality 9.

\section{Coleman J}

1997. Exploding spiritualities. Their social causes, social location and social divide. Christian Spirituality Bulletin 5.

\section{DE BAERE G}

John Ruusbroec. Opera Omnia 10. Tielt-Turnhout.

\section{Fox M}

1982. Educating for transformation. The spiritual task. Horizons 9:74-80.

\section{FrOHLICH M}

1986. Transformations of consciousness. Conventional and contemplative perspectives on development. Boston. 
1990. Mystical transformation. Intersubjectivity and foundations. A study of Teresa of Avila's Interior Castle. Ann Arbor.

HOFMAN G (ED.)

1966. Deutsche mystische Schriften. Düsseldorf.

KAVANAUGH K \& RODRIGUEZ O

1979. Collected works of St. John of the Cross. Washington.

LeclercQ J, TALbOT C \& Rochais H (EDD.)

1957-1977. Sancti Bernardi Opera I-VIII. Rome.

MCGONIGLE T

1993. Three ways. The New Dictionary of Catholic Spirituality, pp. 963-965.

\section{MEISTER ECKHART}

1976. Die deutschen und lateinischen Werke III. Ed. J. Quint. Stuttgart.

\section{MOSELEY R}

1991. Becoming a self before God. Critical transformations. Nashville.

\section{NiCHOLSON R}

1995. Rumi. Poet and mystic. Oxford.

\section{PÖHLMANN W}

1981. Morphè. Exegetisches Wörterbuch zum Neuen Testament II:1089-1091.

\section{SANDAEUS M}

1963. Pro theologia mystica clavis (1640). Heverlee-Leuven.

\section{SCHNEIDERS S}

1998. The study of Christian spirituality. Contours and dynamics of a discipline. Christian Spirituality Bulletin 6.

\section{STRACK H \& BILlERBeCK P}

1924. Kommentar zum Neuen Testament IV. München.

\section{SUSTAR T}

1992. Transforming faith. Reproducing the Christlife. Cleveland.

\section{TURNER G}

1964. The vision which transforms. Is Christian perfection Scriptural? Kansas City.

\section{VALE C}

1990. Mystical consciousness/transformation. An examination of the Christian tradition from a Teilhardian perspective. Ann Arbor.

\section{VAUGHAN-LeE L}

1995. Sufism. The transformation of the heart. Inverness.

\section{WESTERMANN C}

1984. Genesis 1-11. Minneapolis. 
Acta Theologica Supplementum 8

\section{Wiethaus U}

1996. Ecstatic transformation. Transpersonal psychology in the work of Mechthild of Magdeburg. Syracuse.

Keywords

Spirituality

Transformation

Conformation

Glory

Love

Will of God
Trefwoorde

Spiritualiteit

Transformasie

Konformering

Heerlikheid

Liefde

Wil van God 